\title{
THE DECAY OF AN ANNUAL COVER OF SEA ICE
}

\author{
By M. P. Langleben
}

(Ice Research Project, Department of Physics, McGill University, Montreal, Quebec, Canada)

\begin{abstract}
In his now classic book L'dy Arktiki [Arctic ice], Zubov discussed the melting of sea ice during the Arctic summer by thermal interaction with the surrounding water and derived an expression which indicates that the proportion of open water increases exponentially with time until total ice-free conditions result. His equation predicts that the time required for complete decay of the ice cover after initial break-up is greater than one month and more likely as long as two months for representative values of incident shortwave radiation and initial ice thickness upon break-up. It is unlikely that above-freezing temperatures persist for this length of time.

To explain the observed complete disintegration of the annual ice cover in many sheltered areas of the Arctic, a modified model of the thermal decay process has been introduced. This model takes into account the influence of radiation absorbed by the ice which was not included in the Zubov formulation. Considerable reduction in the time required for complete decay, generally by about a factor of 2 if an albedo of 0.4 is assumed for the ice surface, is obtained.
\end{abstract}

RÉsumé. La disparition d'une couverture annuelle de glace de mer. Dans un livre maintenant classique, L'dy Arktiki [Glace Arctique], Zubov expliquait la fusion de la glace de mer pendant l'été Arctique par une interaction thermique avec l'eau environnante, et en déduisait une expression qui indique que la proportion d'eau libre croît exponentiellement avec le temps jusqu'à ce qu'il en résulte des conditions de l'eau totalement libre. Son équation prévoit que le temps nécessaire pour une disparition complète de la couverture de glace après une rupture initiale, dépasse un mois et atteint plus probablement deux mois pour des valeurs convenables de la radiation incidente de courte longueur d'onde et de l'épaisseur initiale de la glace au moment de la rupture initiale. Il est improbable que des températures supérieures au point de fusion subsistent pendant ce laps de temps.

Pour expliquer la désintégration complète que l'on observe de la couverture de glace dans beaucoup de secteurs abrités de l'Arctique, on a introduit un modèle modifié du processus thermique de la disparition de la glace. Ce modèle prend en compte l'influence de la radiation absorbée par la glace qui n'était pas incluse dans la formulation de Zubov. On obtient une réduction considérable dans le temps nécessaire pour une débacle complète, généralement d'un facteur voir de deux, si l'on admet un albedo de 0,4 pour la surface de la glace.

Zusammenfassung. Die Auflösung einer jährlichen Meereisdecke. Zubow hat in seinem nun schon klassischen Buch L'dy Arktiki [Arktisches Eis] das Abschmelzen von Meereis während des arktischen Sommers durch thermische Wechselwirkung mit dem umgebenden Wasser diskutiert und gelangte zu einem Ausdruck, der zeigt, dass der Anteil offenen Wassers exponentiell mit der Zeit anwächst, bis sich völlige Eisfreiheit ergibt. Seine Gleichung sagt voraus, dass die zur vollständigen Auflösung der Eisdecke nach dem anfänglichen Aufbrechen notwendige Zeit bei representativen Werten für die einfallende kurzwellige Strahlung und für die anfängliche Eisdicke vor dem Aufbrechen mehr als ein Monat und eher an die zwei Monate beträgt. Es ist unwahrscheinlich, dass während einer so langen Zeit ständig Temperaturen über dem Gefrierpunkt herrschen.

Zur Erklärung der beobachteten vollständigen Auflösung der jährlichen Eisdecke in vielen geschützten Gebieten der Arktis wurde ein modifiziertes Modell des thermischen Auflösungsprozesses eingeführt. Dieses Modell berücksichtigt den Einfluss der vom Eis absorbierten Strahlung, die in Zubows Ansatz nicht enthalten war. Man erhält eine beträchtliche Reduktion der zur totalen Auflösung notwendigen Zeit, allgemein etwa um den Faktor 2, wenn man eine Albedo von 0,4 für die Eisoberfläche annimmt.

\section{INTRODUCTION}

In many of the sheltered bays, inlets and fiords of the Canadian archipelago and along the Arctic coastline the micro-climate developed during the short summer season is such as to produce complete melting of the ice cover almost every year. A new ice cover forms in the autumn and attains a maximum thickness in the late spring of between about $2 \mathrm{~m}$ and $2.5 \mathrm{~m}$, depending on the latitude. These ice covers are landfast generally and exhibit little motion except during their final stage of decay.

The factors causing the disintegration of an annual ice cover are known reasonably well. A mainly qualitative description of the stages of decay has been given by Zubov (I 945 , chapter 8) and a quantitative study of the processes occurring during the part of the decay when the ice cover is still continuous has been made by Langleben (1966). The coming of the period of $24 \mathrm{~h}$ daylight in the spring, coupled with the relatively high values of insolation 
because of cloud-free conditions, rapidly produces a modification in the snow cover on the ice and reduces the surface albedo. As the season progresses, the solar angle increases and daily totals of short-wave radiation incident on the surface increase and more and more of this energy is absorbed by the ice cover as the albedo decreases. During this time (Langleben, I966) the air-mass temperature is moderating and ultimately climbs to the vicinity of $o^{\circ} \mathrm{C}$, whereupon very rapid melting of the snow cover takes place, the albedo drops to a value of about 0.2 and enough radiation is absorbed by the ice cover to produce an ablation rate of about $4 \mathrm{~cm}$ per day and to modify the temperature profile in the ice cover in the direction of the zero isotherm. After about a week, a system of surface drainage canals and vertical melt holes develop, and the characteristic appearance of the summer ice cover evolves, with its melt ponds and surrounding smooth hummocks. Surface melting continues at about the rate indicated and, by the time the ice cover has been reduced to a thickness of about $\mathrm{I} m$ to I. $5 \mathrm{~m}$, the network of drainage canals developed by the run-off of melt water has produced local erosion serious enough to cause the cover to break up along these flaws under the action of tides or storms.

At this stage, when the ice cover is no longer continuous, the decay process can accelerate by thermal interaction of the ice floes with the sea in spite of the decrease in insolation brought about by the prevalent cloudiness associated with the relatively warm open water. Zubov (1944) has made a quantitative study of this final stage of decay on the assumption that the radiation absorbed by the ice is negligible compared with that absorbed by the water. On this basis, the time required for complete decay is considerably longer than the period available in the Arctic, considering that about a month of above-freezing temperatures are necessary first to thin the ice cover down to a thickness where it can begin to break up under wave, wind or tidal action.

It is the purpose of this paper to show that the period of final decay of the ice cover is reduced considerably if the radiation absorbed by the ice floes is accounted for, and that complete melting of the ice floes by thermal interaction with the surrounding water is then possible during the short Arctic summer.

\section{MODEL}

The model used in this study is based on the following premises.

(a) Immediately on break-up of the continuous ice cover, there exists a finite fraction of open water. The open water is likely to be established very quickly by abrasion between closely packed floes.

(b) The energy input at the surface is determined entirely by the short-wave radiation incident on the surface and by its albedo, be it water or ice. As has been pointed out by Vowinckel and Orvig (1966) the outgoing long-wave radiation from the Earth is very nearly balanced by incoming long-wave radiation from the clouds during the summer season. It has further been shown (Langleben, ig68[b]) that the energy budget of the ice cover during the melt period is almost completely radiation controlled, in that the turbulent energy fluxes of sensible and latent heats to and from the surface are negligibly small.

(c) The radiation absorbed by the water is confined to a relatively shallow layer which is available for heat exchange with the ice floes around their perimeter. There is some support for this assumption in temperature and salinity profiles obtained at this season.

(d) There is no exchange of water or ice in the area under consideration with adjacent areas. It is assumed that these are sheltered areas and can be treated as closed oceanographic systems for the present purpose.

Now, at time $t$, let $S_{\mathrm{w}}$ represent the area of open water over a large area $S$ of the ice cover (i.e. the ice concentration is $\left.\mathrm{I}-S_{\mathrm{w}} / S\right)$. Let $A_{\mathrm{w}}$ be the albedo of the open water and $I$ the 
intensity of incoming solar radiation at the Earth's surface. Then in time $\mathrm{d} t$, the quantity of heat absorbed by the water is $I S_{\mathrm{w}}\left(\mathrm{I}-A_{\mathrm{w}}\right) \mathrm{d} t$.

If, following Zubov (I945), it is assumed that this energy is expended solely in decreasing the horizontal dimensions of the ice floes by melting at the edges without affecting their thickness, then by the method of mixtures the heat balance equation is

$$
I S_{\mathrm{w}}\left(\mathrm{I}-A_{\mathrm{w}}\right) \mathrm{d} t=L \rho h \mathrm{~d} S_{\mathrm{w}}
$$

where $\rho$ is the density of the ice, $L$ its latent heat of fusion, $h$ its thickness at time $t$, and $\mathrm{d} S_{\mathrm{w}}$ the decrease in surface area of the floes which corresponds exactly to the increase in surface area of open water.

That is

$$
\frac{\mathrm{d} S_{\mathrm{w}}}{S_{\mathrm{w}}}=\frac{I\left(\mathrm{I}-A_{\mathrm{w}}\right)}{L \rho h} \mathrm{~d} t .
$$

If $h$ is assumed constant $\left(=h_{0}\right)$, which implies that the radiation absorbed by the ice is negligible compared to that absorbed by the water, and if $I$ is assumed constant then the Zubov solution is obtained, i.e.

$$
S_{\mathrm{w}}=S_{\mathrm{wo}} \exp \left[I\left(\mathrm{I}-A_{\mathrm{w}}\right) t / L \rho h_{\mathrm{o}}\right]
$$

where $S_{\mathrm{wo}}$ is the area of open water at $t=0$ and the equation is valid for $S_{\mathrm{w}} \leqslant S$. This solution has found wide acceptance in the U.S.S.R. and is still cited in recent Russian literature (e.g. Doronin, 1970) although Zubov was aware of its limitations.

A more realistic model of the thermal decay process is obtained by including the influence of solar radiation absorbed by the ice floes. If $A_{\mathrm{i}}$ is the albedo of the ice then, in time $\mathrm{d} t$, the quantity of heat absorbed by the ice is $I\left(S-S_{\mathrm{w}}\right)\left(\mathrm{I}-A_{\mathrm{i}}\right) \mathrm{d} t$.

If this energy is used only to decrease the ice thickness by surface melting, then

$$
I\left(S-S_{\mathrm{w}}\right)\left(\mathrm{I}-A_{\mathrm{i}}\right) \mathrm{d} t=-L \rho\left(S-S_{\mathrm{w}}\right) \mathrm{d} h,
$$

or

$$
\mathrm{d} h=-\frac{I\left(\mathrm{I}-A_{\mathrm{i}}\right)}{L \rho} \mathrm{d} t .
$$

It should be noted that the ice cover is assumed to be near its melting point throughout its thickness and that the loss, by radiation penetration through the bottom of the ice cover, of the available energy is neglected. Chernigovskiy ( 1963 ) states that about 3 to $4 \%$ of the incoming radiation is able to penetrate through pack ice of thickness $\mathrm{I} .5 \mathrm{~m}$ and that the proportion increases with decreasing ice thickness. The neglect of this factor in the model would tend to overestimate slightly the rate of decay of the ice. However internal melting at the brine cells, which is produced by radiation absorption within the ice, brings about a compensating effect in that the actual surface ablation rate is less than that calculated from the model and hence the ice floes present a larger perimeter area for thermal interaction with the sea. In any case, the loss of radiant energy by penetration through the ice cover is expected to be less for annual or first-year ice than for pack ice. Because of its higher salinity, first-year ice is more opaque than multi-year ice.

Equation ( $\mathrm{I}$ ) can be solved numerically by stepwise integration in combination with the ice thickness-time relationship as given by Equation (3), even in the case where $I$ and/or $A_{\mathrm{i}}$ vary with time. There is however insufficient knowledge of the day-to-day variations of these quantities except for point measurements at selected sites for limited periods. It is reasonable therefore to assume constant values of $I$ and $A_{\mathrm{i}}$ based on available data, providing the full range of variation of these parameters is considered. In that case Equation (3) is integrable and

$$
h=h_{\mathrm{o}}-\frac{I\left(\mathrm{I}-A_{\mathrm{i}}\right) t}{L \rho}
$$

where $h_{0}$ is the ice thickness at time $t=0$. 
Substituting Equation (4) into Equation (I), we obtain

i.e.

$$
\begin{gathered}
\frac{\mathrm{d} S_{\mathrm{w}}}{S_{\mathrm{w}}}=\frac{I\left(\mathrm{I}-A_{\mathrm{w}}\right)}{L \rho\left[h_{\mathrm{o}}-I\left(\mathrm{I}-A_{\mathrm{i}}\right) t / L \rho\right]} \mathrm{d} t \\
\frac{S_{\mathrm{w}}}{S_{\mathrm{wo}}}=\left[\mathrm{I}-\frac{I\left(\mathrm{I}-A_{\mathrm{i}}\right) t}{L \rho h_{0}}\right]-\left(\mathrm{I}-A_{\mathrm{w}}\right) /\left(\mathrm{I}-A_{\mathrm{i}}\right)
\end{gathered}
$$

where $S_{\mathrm{w}}=S_{\mathrm{wo}}$ at $t=\mathrm{o}$.

It is customary to describe an ice cover in terms of ice concentration, $\mathrm{I}-S_{\mathrm{W}} / S$. The solution in this form is

$$
\mathrm{I}-S_{\mathrm{w}} / S=\mathrm{I}-\frac{S_{\text {wo }}}{S}\left[\mathrm{I}-\frac{I\left(\mathrm{I}-A_{\mathrm{i}}\right) t}{L \rho h_{0}}\right]-\left(\mathrm{I}-A_{\mathrm{w}}\right) /\left(\mathrm{I}-A_{\mathrm{i}}\right)
$$

valid until time $T$ corresponding to the complete decay of the ice cover, or to zero concentration, where

$$
T=\frac{L \rho h_{\mathrm{o}}}{I\left(\mathrm{I}-A_{\mathrm{i}}\right)}\left[\mathrm{I}-\left(\frac{S_{\mathrm{wo}}}{S}\right)\left(\mathrm{I}-A_{\mathrm{i}}\right) /\left(\mathrm{I}-A_{\mathrm{w}}\right)\right]
$$

\section{Calgulations and Results}

Equation (6) has been used to calculate the variation of ice concentration with time intervals of one day up until the time for complete decay as given by Equation (7). The following values were taken for the constants and initial conditions in these equations.

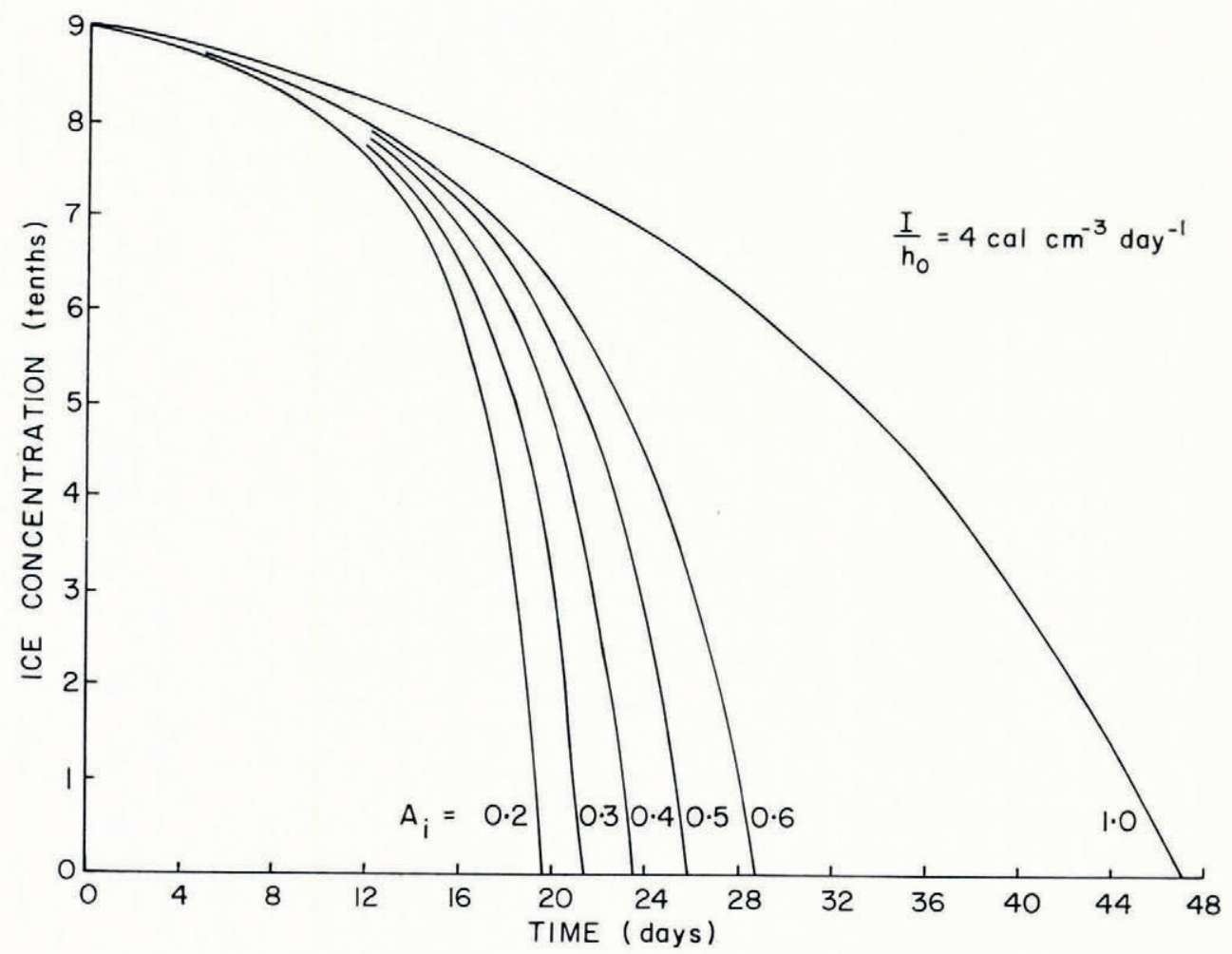

Fig. I. Ice concentration as function of elapsed time after initial break-up for various values of ice albedo $A_{1}$. The ratio of incident short-wave radiation I to initial ice thickness $h_{0}$ is $4 \mathrm{cal} \mathrm{cm}^{-3} d^{-1}\left(194 \mathrm{~W} \mathrm{~m}^{-3}\right)$. 
Initial ice concentration $\mathrm{I}-S_{\mathrm{wo}} / S=9 / \mathrm{Io}$,

Albedo of water

Density of ice

$$
\begin{aligned}
A_{\mathrm{w}} & =0 . \mathrm{I}, \\
\rho & =0.9 \mathrm{Mg} \mathrm{m}^{-3}, \\
L & =80 \mathrm{cal} \mathrm{g}^{-1}\left(3.34 \times 10^{5} \mathrm{~J} \mathrm{~kg}^{-1}\right) .
\end{aligned}
$$

Latent heat of fusion

The calculations were performed for a number of values of albedo of ice, incident short-wave radiation and initial ice thickness within the range of these parameters typical of the summer melt period.

\section{Albedo of ice floes}

The albedo $A_{\mathrm{i}}$ was allowed to assume in turn values of $0.2,0.3,0.4,0.5,0.6$ and, in addition, r.o to obtain the Zubov solution. Continuous measurements by Langleben (1969) during the melt period indicate a variation of albedo in the range 0.2 to 0.5 which is quantitatively related to the degree of puddling of the surface. Values of albedo also have been reported by Marshunova (I96I) as about 0.2 in coastal areas and by Chernigovskiy (I963) as about 0.45 on a drifting station. The value of 0.6 was included to obtain a conservative estimate on the decay.

\section{Incident short-wave radiation}

Values of $I$ of $400 \mathrm{cal} \mathrm{cm}^{-2} \mathrm{day}^{-1}\left(\mathrm{I} 94 \mathrm{~W} \mathrm{~m}^{-2}\right), 500 \mathrm{cal} \mathrm{cm}^{-2} \mathrm{day}^{-1}\left(242 \mathrm{~W} \mathrm{~m}^{-2}\right)$ and $600 \mathrm{cal} \mathrm{cm}^{-2}$ day $^{-1}\left(29 \mathrm{I} \mathrm{W} \mathrm{m} \mathrm{W}^{-2}\right)$ were used. Measurements in heavy overcast within this

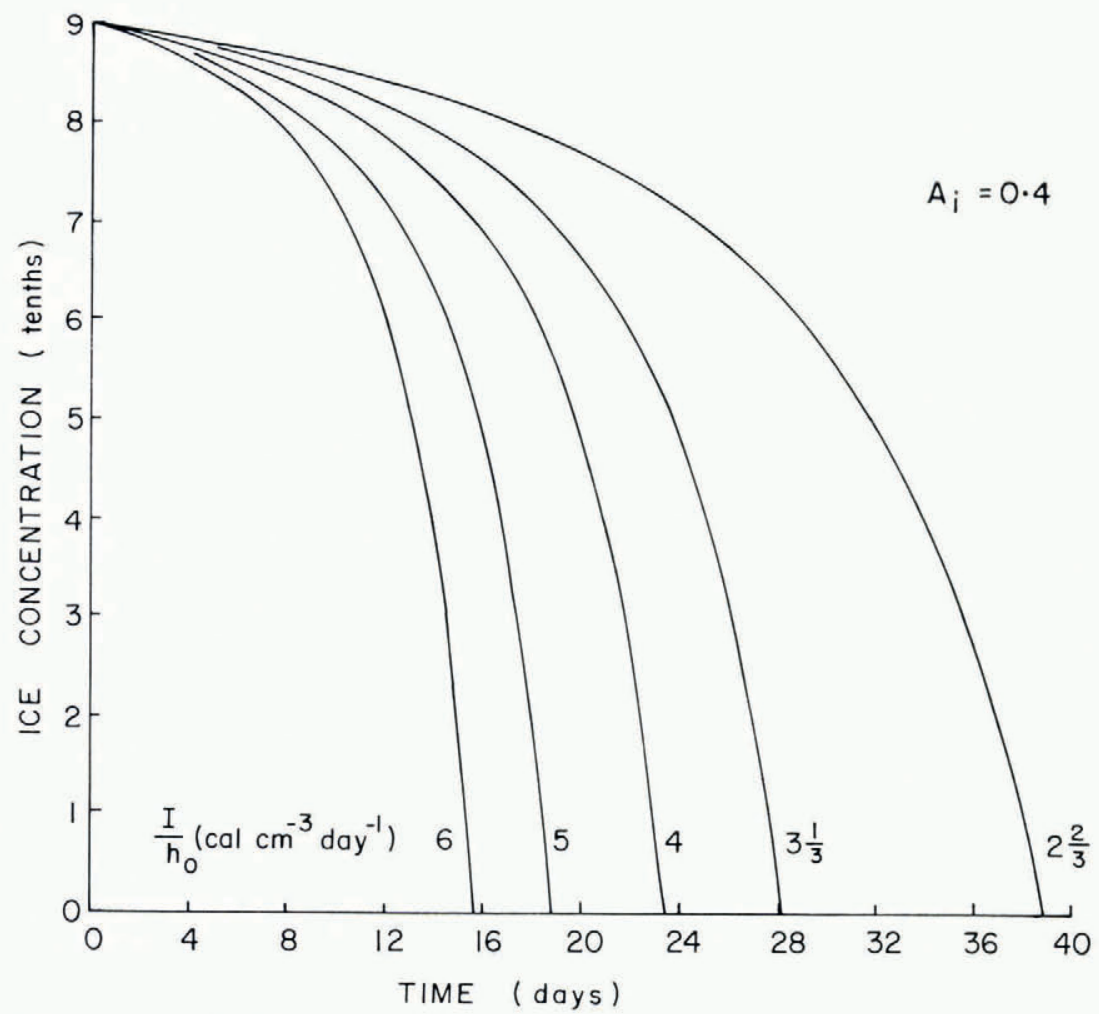

Fig. 2. Ice concentration as function of elapsed time after initial break-up for various values of the ratio of incident short-wave radiation I to initial ice thickness $h_{0}$. The albedo of ice is assumed to be 0.4 . 
range and in excess have been obtained by Langleben (1966, I968[a], 1969), and values of this magnitude under similar conditions were used by Vowinckel and Orvig (1964) in their energy-balance study of the Arctic.

\section{Ice thickness}

Initial ice thickness $h_{0}$ on break-up was selected as I m or $1.5 \mathrm{~m}$. As discussed in the Introduction, it is at this stage of the thermal decay that the ice cover is observed to break up.

Some of the results of these calculations are shown in Figures I, 2 and 3 . A family of curves of ice concentration against time has been plotted in Figure I for various values of the albedo of ice. The ratio of incident radiation to initial ice thickness was taken as $4 \mathrm{cal} \mathrm{cm}^{-3} \mathrm{~d}^{-\mathrm{r}}$ ( $\left.194 \mathrm{~W} \mathrm{~m}^{-3}\right)$, corresponding for example to an $I$ of $400 \mathrm{cal} \mathrm{cm}^{-2} \mathrm{~d}^{-1}\left(\mathrm{I} 94 \mathrm{~W} \mathrm{~m}^{-2}\right.$ ) and an $h_{0}$ of $\mathrm{I} \mathrm{m}$, an $I$ of $500 \mathrm{cal} \mathrm{cm}^{-2} \mathrm{~d}^{-1}\left(243 \mathrm{~W} \mathrm{~m}^{-2}\right)$ and an $h_{0}$ of $1.25 \mathrm{~m}$, or an $I$ of $600 \mathrm{cal} \mathrm{cm}^{-2} \mathrm{~d}^{-1}$ $\left(292 \mathrm{~W} \mathrm{~m}^{-2}\right)$ and an $h_{0}$ of $1.5 \mathrm{~m}$. Similar calculations were made within the range $6 \mathrm{cal} \mathrm{cm}^{-3}$ $\mathrm{d}^{-1}>I / h_{0}>2 \mathrm{cal} \mathrm{cm}^{-3} \mathrm{~d}^{-1}\left(292 \mathrm{~W} \mathrm{~m}^{-3}>I / h_{0}>97 \mathrm{~W} \mathrm{~m}^{-3}\right)$ but are not reproduced here. It is seen in Figure I that, as might be anticipated, the ice concentration decreases more and more rapidly as the albedo of the ice surface is reduced from 0.6 to 0.2 in steps of o.I. This cluster of curves is compared with the Zubov solution of Equation (2) where it is assumed that no radiation is absorbed by the ice, i.e. $A_{\mathrm{i}}=$ I.o. The enhancement of the decay process by the absorption of radiation in the ice is clearly evident.

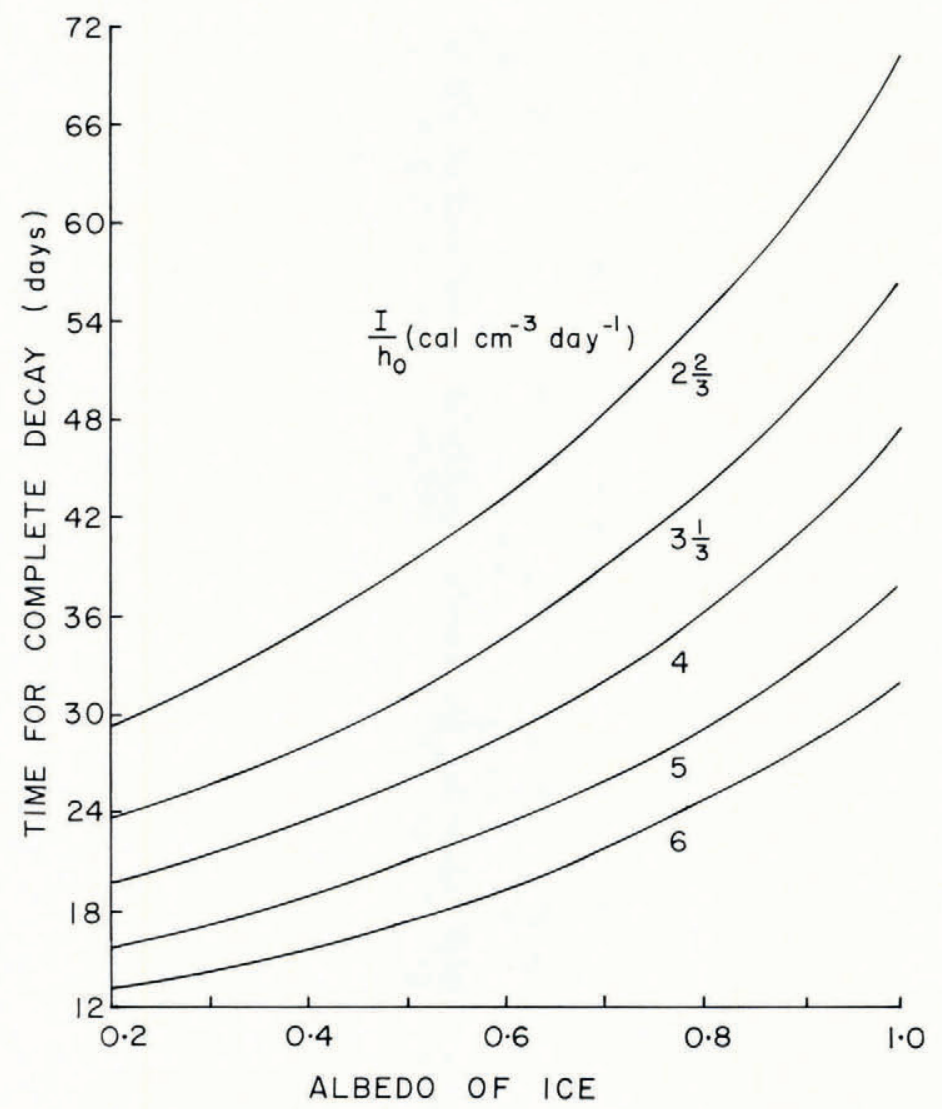

Fig. 3. Time required for complete decay of the ice cover after initial break-up as function of albedo of ice surface for various values of $I / h_{0}$. 
In Figure 2, ice concentration is again plotted as a function of time after initial break-up. This time, however, loci are presented for a number of values of the ratio of incident radiation to initial ice thickness. These were calculated for an albedo of the ice surface of 0.4 , selected as typical of mid-range values of this variable. The extreme values of $I / h_{0}$ used in the calculations were $6 \mathrm{cal} \mathrm{cm}^{-3} \mathrm{~d}^{-1}\left(292 \mathrm{~W} \mathrm{~m}^{-3}\right)$ (corresponding say to an $I$ of $600 \mathrm{cal} \mathrm{cm}^{-2} \mathrm{~d}^{-1}$ $\left(292 \mathrm{~W} \mathrm{~m}^{-2}\right)$ and an $h_{0}$ of $\mathrm{I} \mathrm{m}$ ) and $2.67 \mathrm{cal} \mathrm{cm}^{-3} \mathrm{~d}^{-1}$ ( $129 \mathrm{~W} \mathrm{~m}^{-3}$ ) (corresponding to $I=400$ cal $\mathrm{cm}^{-2} \mathrm{~d}^{-1}\left(\mathrm{I} 94 \mathrm{~W} \mathrm{~m}^{-2}\right)$ and $\left.h_{0}=\mathrm{I} .5 \mathrm{~m}\right)$. If the same value of $h_{0}$ is assumed for each of the curves then Figure 2 can be said to show the variation of the rate of decay of the ice cover with incident radiation, and vice versa. For example if $h_{0}=\mathrm{I} \mathrm{m}$, a change in incident radiation from $267 \mathrm{cal} \mathrm{cm}^{-2} \mathrm{~d}^{-1}\left(\mathrm{I} 30 \mathrm{~W} \mathrm{~m} \mathrm{~W}^{-2}\right)$ to $333 \mathrm{cal} \mathrm{cm}^{-2} \mathrm{~d}^{-1} \quad\left(\mathrm{I} 62 \mathrm{~W} \mathrm{~m}^{-2}\right.$ ) (i.e. of $\left.67 \mathrm{cal} \mathrm{cm}^{-2} \mathrm{~d}^{-1}\left(32 \mathrm{~W} \mathrm{~m}^{-2}\right)\right)$ reduces the time required to obtain a $\frac{1}{10}$ ice concentration by about io d, whereas if $I$ is increased from $500 \mathrm{cal} \mathrm{cm}^{-2} \mathrm{~d}^{-1}\left(243 \mathrm{~W} \mathrm{~m}^{-2}\right)$ to $600 \mathrm{cal} \mathrm{cm}^{-2} \mathrm{~d}^{-1}$ $\left(292 \mathrm{~W} \mathrm{~m}^{-2}\right)$ the reduction in time is only about $3 \mathrm{~d}$.

Figure 3 shows the time for complete decay of the ice cover, as given by Equation ( 7 ), plotted as a function of the albedo of the ice cover, with loci for the same values of $I / h_{0}$ as in the previous diagram. It is seen that the time for complete decay increases with increasing value of ice albedo and with decreasing value of $I / h_{0}$. The curves are continued to $A_{\mathrm{i}}=$ i.o to indicate the decay times that would be obtained from the Zubov equation. It is seen that the required times for all values of $I / h_{0}$ are about twice as large as those for the case when an albedo for the ice surface of 0.4 is used.

\section{Discussion}

The Zubov equation predicts that the time required for complete decay of the ice cover after initial break-up is greater than one month and as long as two months (Fig. 3) for representative values of incident short-wave radiation and initial ice thickness upon break-up. It is unlikely that above-freezing temperatures persist for this length of time.

To explain the observed complete disintegration of the annual ice cover in many sheltered areas of the Arctic, a modified model of the thermal decay process has been introduced. This model takes into account the influence of radiation absorbed by the ice which was not included in the Zubov formulation. Considerable reduction in the time required for complete decay, generally by about a factor of 2 if an albedo of 0.4 is assumed for the ice surface, is obtained.

MS. received 25 October 197 I

\section{REFERENCES}

Chernigovskiy, N. T. 1963. Radiatsionnyye svoystva ledyanogo pokrova tsentral'noy Arktiki [Radiation properties of the ice cover of the central Arctic]. Trudy Arkticheskogo i Antarkticheskogo Nauchno-Issledovatel'skogo Instituta, Tom 253, p. 249-6o.

Doronin, Yu. P. I970. K metodike rascheta splochennosti i dreyfa l'dov [On methods of calculating the compactness and drift of ice floes]. Trudy Arkticheskogo $i$ Antarkticheskogo Nauchno-Issledovatel'skogo Instituta, Tom $29 \mathrm{I}$, p. $5^{-17}$.

Langleben, M. P. 1966. On the factors affecting the rate of ablation of sea ice. Canadian Journal of Earth Sciences, Vol. 3 , No. 4, p. $43 \mathrm{I}-39$.

Langleben, M. P. I968[a]. Albedo measurements of an Arctic ice cover from high towers. Fournal of Glaciology, Vol. 7, No. 50, p. 289-97.

Langleben, M. P. $1968[\mathrm{~b}]$. The heat budget of a melting cover of sea ice. Union de Géodésie et Géophysique Internationale. Association Internationale d'Hydrologie Scientifique. Assemblée générale de Berne, 25 sept. 7 oct. I967. [Commission de Neiges et Glaces.] Rapports et discussions, p. I $5 \mathrm{I}-60$.

Langleben, M. P. 1969. Albedo and degree of puddling of a melting cover of sea ice. Journal of Glaciology, Vol. 8, No. 54, p. 407-12. 
Marshunova, M. S. I96r. Osnovnyye zakonomernosti radiatsionnogo balansa podstilayushchey poverkhnosti i atmosfery $v$ Arktike [Principal characteristics of the radiation balance of the underlying surface and of the atmosphere in the Arctic]. Trudy Arkticheskogo i Antarkticheskogo Nauchno-Issledovatel'skogo Instituta, Tom 229, p. $5-53$.

Vowinckel, E., and Orvig, S. 1964. Energy balance of the Arctic. I. Incoming and absorbed solar radiation at the ground in the Arctic. Archiv für Meteorologie, Geophysik und Bioklimatologie, Ser. B, Bd. 13, Ht. 3, p. 353-77. Vowinckel, E., and Orvig, S. 1966. Energy balance of the Arctic. V. The heat budget over the Arctic Ocean. Archiv für Meteorologie, Geophysik und Bioklimatologie, Ser. B, Bd. 14, Ht. 3-4, p. 303-25.

Zubov, N. N. 1945. L'dy Arktiki [Arctic ice]. Moscow, Izdatel'stvo Glavsermorputi. 